\title{
GEOMORFOLOGI LERENG BARATDAYA GUNUNGAPI MERAPI KAITANNYA DENGAN UPAYA PENGELOLAAN LINGKUNGAN DAN KEBENCANAAN
}

\author{
Oleh: \\ Sriadi Setyawati dan Arif Ashari \\ Jurusan Pendidikan Geografi FIS Universitas Negeri Yogyakarta \\ sriadi s@uny.ac.id
}

\begin{abstract}
Abstrak
Penelitian ini dilakukan pada wilayah lereng baratdaya Gunungapi Merapi dengan tujuan: (1) menganalisis kondisi geomorfologi dengan teknik survei geomorfologikal analitikal, (2) mengembangkan model pengelolaan lingkungan dan kebencanaan berdasakan informasi geomorfologis. Metode yang digunakan adalah eksploratif-survei, dengan pendekatan keruangan. Populasi dalam penelitian ini adalah seluruh wilayah lereng baratdaya Gunungapi Merapi. Sampel diambil dengan teknik purposif sampling pada setiap satuan morfologi. Analisis menggunakan cara deskriptif kualitatif dilandasi aspek dan konsep dasar geomorfologi. Analisis ini didukung dengan analisis pengharkatan untuk menilai potensi sumberdaya alam pada masing-masing satuan bentuklahan. Hasil penelitian: (1) geomorfologi lereng baratdaya Gunungapi Merapi terdiri dari berbagai bentuklahan yang memiliki perbedaan relief, batuan, stuktur, dan proses geomorfologi. Perbedaan tersebut mempengaruhi variasi potensi sumberdaya dan jenis bahaya. (2) pengelolaan lingkungan dan kebencanaan dilakukan dengan identifikasi potensi sumberdaya berdasarkan kondisi geomorfologis dan bentuk pengelolaan yang dapat dilakukan, serta mengidentifikasi jenis bahaya pada setiap bentuklahan dan melakukan penataan ruang berbasis mitigasi bencana.
\end{abstract}

Kata kunci: Geomorfologi, Merapi, Pengelolaan Lingkungan, Pengelolaan Kebencanaan

\begin{abstract}
This research was conducted on the southwestern flank of Merapi volcano aiming at (1) analyzing geomorphological conditions by employing geomorphological-analytical survey techniques, (2) developing environmental and disaster management models based on geomorphological information. The research method is an explorative-survey utilizing a spatial approach. The population in this research includes all regions in the southwestern slopes of Merapi Volcano. The samples were taken using a purposive sampling technique on each morphology unit. The analysis utilizes a qualitative descriptive method based on the aspects and basic concepts of geomorphology. This analysis is supported by an exploratory analysis to assess the potential of natural resources in each unit of landform. The results are: (1) geomorphology of the southwestern slopes of Merapi Volcano consists of various forms of land which have different reliefs, rocks, structures, and geomorphological processes. These differences affect the variation of potential resources and types of hazards. (2) Environmental and disaster management is performed by identifying potential resources based on geomorphological conditions and type of management that can be carried out, identifying the types of hazards on each landform and conducting spatial planning based on disaster mitigation.

Keywords: Geomophology, Merapi, Environmental Management, Disaster Management.
\end{abstract}




\section{PENDAHULUAN}

Risiko bencana di Indonesia masih tergolong tinggi. Hal ini disebabkan oleh banyaknya jenis bahaya yang mengancam, meningkatnya jumlah manusia yang rentan terhadap ancaman bencana, serta masih rendahnya kemampuan masyarakat dalam menghadapi bencana (Sudibyakto, 2007; Lavigne, 2010). Salah satu wilayah dengan risiko bencana tinggi di Indonesia adalah Gunungapi Merapi yang sering disebut sebagai gunungapi paling aktif selama holosen. Sejak tahun 1006 Gunungapi Merapi terus mengalami letusan secara reguler dengan rentang antara satu hingga tujuh tahun sekali dan hingga saat ini tercatat telah mengalami letusan hingga lebih dari 80 kali. Atas dasar inilah Merapi sering disebut sebagai never sleeps volcano (Andreastuti dkk, 2006; Sudradjat dkk, 2010; Putra dkk, 2011; Sudibyakto, 2011ª). Risiko bencana juga didorong oleh peningkatan jumlah penduduk di wilayah ini dengan rata-rata mencapai 2,8\%, melebihi pertumbuhan penduduk rata-rata nasional sebesar 2,5\% (Sudibyakto, 2011 b).

Berdasarkan amanat dalam UU Nomor 24 Tahun 2007 tentang penanggulangan bencana dan PP Nomor 21 tahun 2008 tentang penyelenggaraan penanggulangan bencana, risiko bencana dapat dikurangi dengan melakukan tindakan pengelolaan kebencanaan. Dalam pengelolaan kebencanaan terdapat tiga bagian pokok yaitu mitigasi dan kesiapsiagaan, respon, dan pemulihan. Mitigasi mencakup pembangunan kapasitas (kemampuan menghadapi bencana) dan monitoring pra bencana, respon (tanggap darurat) mencakup observasi situasi kritis dan analisis data yang berhubungan dengan dampak bencana, sedangkan pemulihan mencakup dukungan-dukungan yang diperlukan selama proses pemulihan pasca bencana (Kaku dan Held, 2013). Untuk dapat melaksanakan berbagai kegiatan dalam siklus pengelolaan bencana dengan baik diperlukan data dan informasi pendukung. Informasi mengenai kondisi fisik suatu wilayah sangat dibutuhkan khususnya dalam tahap mitigasi dan kesiapsiagaan.

Kondisi fisik suatu wilayah sangat berkaitan dengan tingkat bahaya wilayah tersebut. Dengan demikian informasi mengenai kondisi fisik khususnya morfologi pada suatu wilayah dapat dimanfaatkan sebagai referensi dalam perencanaan tindakan penanggulangan bencana. Hadi dan Setyawati (2014) dalam penelitian mengenai risiko bencana di wilayah lereng selatan dan baratdaya Gunungapi Merapi menunjukkan bahwa informasi kondisi fisik wilayah sangat diperlukan dalam penilaian risiko bencana, khususnya pada aspek bahaya dan kerentanan. Untuk menghasilkan informasi risiko bencana secara detail perlu didukung oleh ketersediaan data hasil survei geomorfologi dalam skala besar.

Sebagai vulkan aktif, Gunungapi Merapi tidak hanya memiliki potensi bahaya namun disisi lain juga memiliki potensi sumberdaya alam yang tinggi antara lain berupa sumberdaya lahan, sumberdaya air, sumberdaya hayati, dan sumberdaya mineral (Sutikno dkk, 2007). Dalam upaya melakukan pengelolaan berbagai sumberdaya tersebut, agar dapat terlaksana secara efektif dan efisien serta menghindarkan kesalahan pengelolaan (malfunction) perlu didukung oleh informasi geomorfologi. Kondisi bentanglahan khususnya tanah, geologis, hidrologis, dan vegetasi sangat berkaitan dengan karakteristik geomorfologis, sehingga pendekatan geomorfologis sangat relevan untuk analisis potensi 
dan recana pengelolaan berbagai jenis sumberdaya tersebut (Verstappen, 1983; Sutikno, 1987).

Survei geomorfologikal analitikal merupakan salah satu metode dalam geomorfologi untuk mendapatkan keterangan yang lengkap mengenai kondisi suatu bentanglahan. Metode survei ini menekankan penyediaan informasi geomorfologi secara lengkap dan mendalam yaitu meliputi aspek morfografi, morfometri, morfogenetik, dan morfokronologi. Metode ini merupakan pasangan dari survei sintetik medan dan bersifat saling melengkapi. Para ahli geomorfologi telah cukup lama menggunakan metode ini untuk kajian kebencanaan dan pengelolaan sumberdaya alam. Hal ini didasarkan pada kenyataan bahwa distribusi dan klasifikasi bentuklahan serta fenomena yang terkait sangat penting untuk dipertimbangkan dalam pengelolaan sumberdaya alam agar dapat dilakukan pemanfaatan yang rasional. Hasil analisis geomorfologikal yang disajikan dalam bentuk peta dapat diterapkan untuk berbagai aspek manajemen lingkungan (Verstappen, 2014). Melalui survei geomorfologikal analitikal akan diperoleh informasi yang lengkap mengenai karakteristik morfologi lereng baratdaya Gunungapi Merapi, sebagai sumbangan referensi untuk pengelolaan kebencanaan dan lingkungan.

\section{METODE}

Penelitian ini merupakan penelitian eksploratif dengan pendekatan geografi yaitu pendekatan keruangan. Terkait dengan karakteristik obyeknya, penelitian ini merupakan penelitian survei. Jenis survei yang digunakan adalah survei normatif. Terkait dengan populasinya penelitian ini menggunakan sampling, dan terkait dengan analisis penelitian ini menggunakan kombinasi antara analisis kuantitatif dan kualitatif. Populasi dalam penelitian ini adalah seluruh wilayah lereng baratdaya Gunungapi Merapi. Pengambilan sampel dilakukan dengan teknik purposif sampling pada setiap satuan morfologi. Penentuan satuan morfologi dilakukan dengan mengacu pada model satuan morfologi gunungapi strato yang dibedakan ke dalam beberapa segmen yaitu bagian atas, tengah, dan bawah (Verstappen, 2013), atau secara lebih rinci menjadi kerucut vulkan, lereng vulkan, kaki vulkan, dataran fluvio kaki vulkan, dan dataran fluviovulkan (Simoen, 2001; Sutikno dkk, 2007). Pembagian satuan morfologi ini selain didasarkan pada perbedaan kenampakan fisik maupun ukuran kuantitatif lereng dan reliefnya juga didasarkan pada perbedaan genesis dan proses geomorfologi yang berlangsung. Perbedaan genesis dan proses geomorfologi menentukan perbedaan morfologi dan morfometrinya.

Pengumpulan data dilakukan dengan observasi, dokumentasi, studi pustaka, dan interpretasi citra penginderaan jauh. Survei geomorfologikal analitikal merupakan bentuk observasi secara langsung dalam survei geomorfologi. Analisis yang digunakan dalam penelitian ini adalah analisis deskriptif kualitatif didukung dengan analisis pengharkatan. Interpretasi dalam analisis dilakukan dengan memperhatikan aspek kajian dan konsepkonsep geomorfologi, kriteria pengelolaan kebencanaan dalam tahap mitigasi, dan kriteria pengelolaan lingkungan dengan perencanaan tata guna lahan. Untuk menjawab masalah pertama analisis deskriptif kualitatif digunakan dengan memperhatikan aspekaspek kajian dan konsep-konsep geomorfologi. Informasi geomorfologi terdiri dari 
bentuklahan, genesis, proses, dan lingkungan (Verstappen, 2014). Untuk menjawab masalah ke dua, analisis deskriptif kualitatif digunakan dengan memperhatikan kriteria dalam pengelolaan kebencanaan dan lingkungan. Dalam pengelolaan kebencanaan salah satu tahap yang dapat didukung dengan informasi geomorfologis adalah mitigasi bencana sehingga analisis perlu memperhatikan kriteria dalam mitigasi bencana. Adapun dalam pengelolaan lingkungan, analisis diarahkan untuk melakukan penilaian potensi sumberdaya alam.

\section{HASIL DAN PEMBAHASAN}

\section{Daerah Penelitian}

Daerah penelitian meliputi lereng baratdaya Gunungapi Merapi, Kecamatan Srumbung, Salam, dan Ngluwar, Kabupaten Magelang, yang terletak pada 424000 hingga 438000 MT serta 9150000 hingga 9168000 MU pada koordinat UTM zona 49 (Gambar 1). Daerah penelitian dibatasi oleh Sungai Krasak di bagian timur dan Sungai Blongkeng di bagian barat. Kondisi geologi daerah penelitian cukup kompleks dengan berbagai hasil aktivitas vulkanik dari periode Gunungapi Merapi muda, antara lain Endapan Gunungapi Merapi Muda (Qmi), Endapan Longsoran dari Awan Panas (na), Kubah lava dan leleran (d), dan Endapan Gunungapi Merapi Tua (Qmo). Daerah penelitian berada pada zona peralihan antara satuan morfologi lereng gunungapi dengan kaki gunungapi. Sutikno dkk (2007) menjelaskan, wilayah lereng dan kaki gunungapi memiliki potensi hujan sedang dengan rerata curah hujan tahunan $1734 \mathrm{~mm}$ untuk lereng gunungapi dan $1550 \mathrm{~mm}$ untuk kaki gunungapi. Berdasarkan klasifikasi iklim Schmidt-Ferguson kedua wilayah tersebut termasuk dalam tipe Iklim C, sedangkan menurut klasifikasi Oldeman termasuk dalam tipe iklim B2. Secara hidrologis daerah penelitian memiliki potensi akuifer yang baik.

\section{Geomorfologi Lereng Baratdaya Gunungapi Merapi}

Pembahasan mengenai kondisi Geomorfologi tidak terlepas dari bentuklahan, genesis, dan proses geomorfologi yang berlangsung di dalamnya. Bentuklahan dalam hal ini berada pada bagian yang sangat penting karena proses geomorfologi yang terjadi akan berkembang sesuai dengan watak bentuklahannya (Thornbury, 1959). Sutikno dkk (2007) menjelaskan bahwa Gunungapi Merapi merupakan suatu bentanglahan yang mempunyai kekhasan baik genesis, material penyusun, maupun strukturnya. Gunungapi Merapi merupakan gunungapi tipe strato yang secara umum morfologinya dikelompokkan menjadi lima bagian yaitu kerucut gunungapi, lereng gunungapi, kaki gunungapi, dataran kaki gunungapi, dan dataran fluvial gunungapi. Secara lebih rinci di daerah penelitian terdapat bentuklahan kepundan, medan lahar, medan lava, kerucut gunungapi, lereng gunungapi, kaki gunungapi, dataran kaki gunungapi, dan perbukitan terisolasi. Bentuklahan-bentuklahan tersebut memiliki perbedaan relief, batuan, stuktur, dan proses geomorfologi yang berlangsung. 


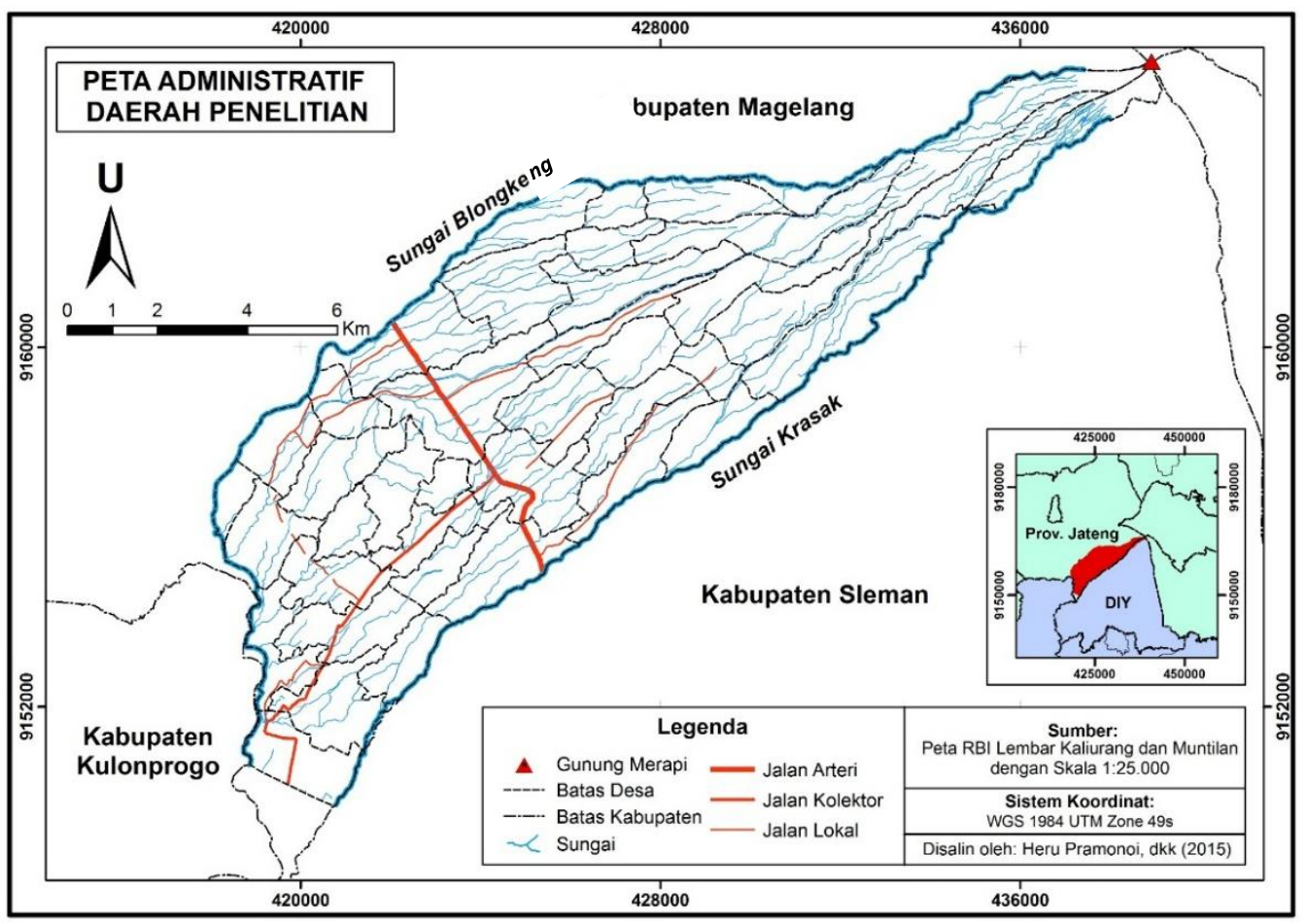

Gambar 1. Daerah Penelitian

Geomorfologi Gunungapi Merapi sangat berkaitan dengan jenis dan sebaran bahaya yang ditimbulkannya. Aktivitas vulkanik Gunungapi Merapi telah membentuk bentangan morfologi yang luas namun disisi lain juga mampu mengubah bentanglahan yang telah terbentuk (Sutikno dkk, 2007). Wilayah yang dikaji dalam penelitian ini meliputi lereng baratdaya Gunungapi Merapi yang termasuk dalam bagian Merapi Muda. Sebagai wilayah vulkan muda, bentuklahan pada lereng baratdaya sangat kompleks yang mencirikan vulkan komposit aktif yaitu terdiri dari kepundan, kerucut gunungapi, lereng gunungapi, kaki gunungapi, dan dataran kaki gunungapi. Disamping itu terdapat pula bentuklahan perbukitan terisolasi serta bentuklahan yang spesifik hasil dari aktivitas vulkanik masa lampau yaitu medan lava dan medan lahar (Gambar 2).

Bentuklahan kepundan merupakan depresi volkanis dengan ciri-ciri bentuk depresi pada puncak kerucut Gunungapi Merapi (Sutikno dkk, 2007). Wilayah ini terbentuk dari pengendapan material lava dan piroklastik. Berdasarkan klasifikasi fasies gunungapi, kepundan termasuk dalam fasies sentral yang merupakan pusat aktivitas vulkanik. (Gambar 3a). Ditinjau dari genesisnya, bentuklahan ini terbentuk oleh proses erupsi dan merupakan pusat erupsi yang masih aktif hingga saat ini. Proses geomorfologi yang berlangsung adalah erupsi (Sutikno dkk, 2007). Dalam proses erupsi ini dapat terjadi penghancuran morfologi maupun pembentukan morfologi. Penghancuran morfologi kepundan terjadi apabila terdapat letusan yang eksplosif, sedangkan pembentukan morfologi terjadi apabila terdapat pengendapan material erupsi maupun pembentukan kubah lava. 


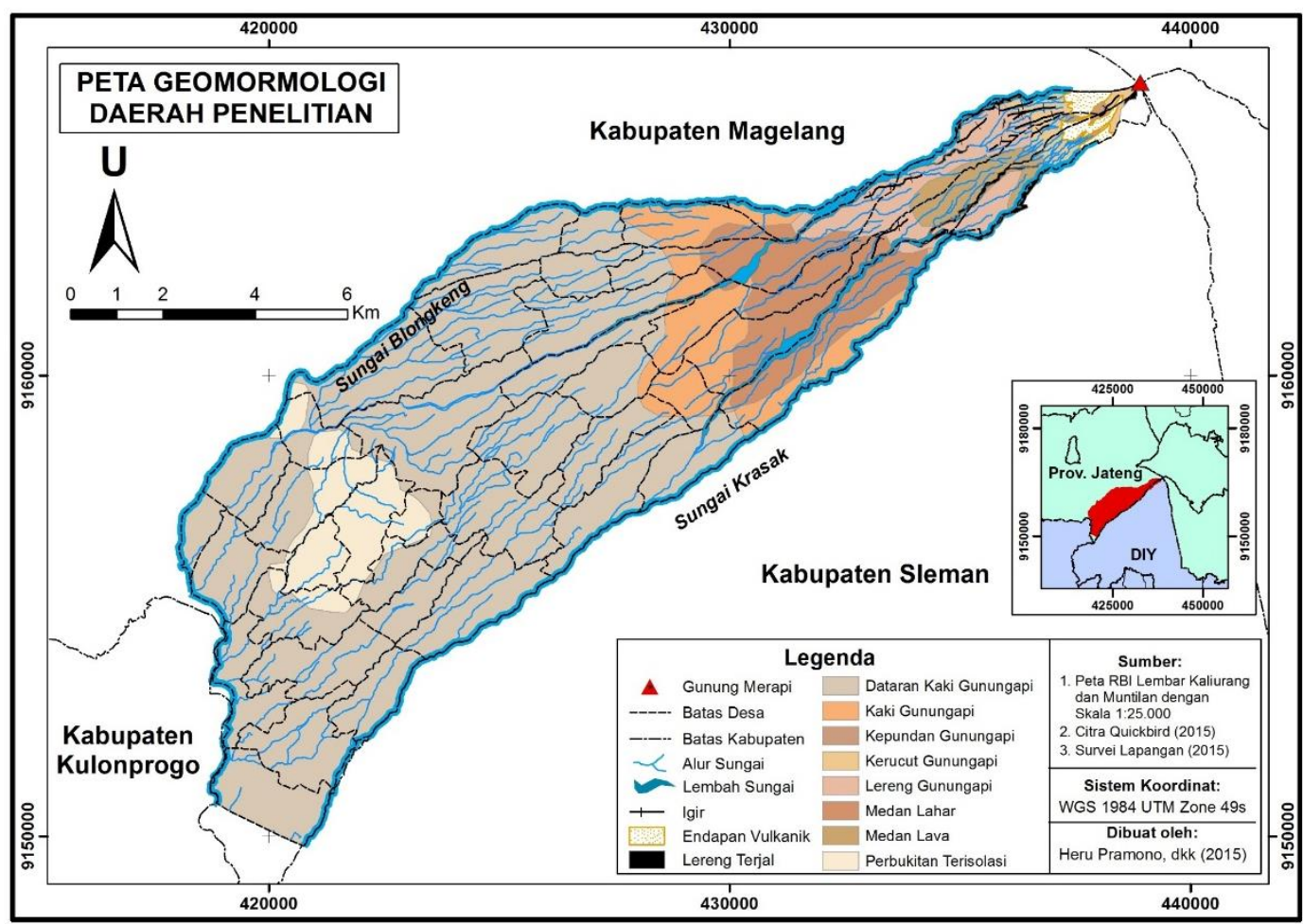

Gambar 2. Peta Geomorfologi Lereng Baratdaya Gunungapi Merapi

Bentuklahan kerucut gunungapi memiliki relief berbentuk kubah tersusun oleh endapan piroklastik dan aliran lava. Wilayah ini meliputi tubuh Gunungapi Merapi bagian paling atas dengan lereng paling curam (Sutikno dkk, 2007). Dalam klasifikasi fasies gunungapi, bentuklahan kerucut gunungapi termasuk dalam fasies piroksimal yang kedudukannya berdekatan dengan pusat erupsi. Verstappen (2013) menjelaskan kerucut gunungapi terbentuk oleh proses pengendapan abu dan atau abu klastik yang berasal dari hancuran sumbat lava, jatuhan atau longsor di bawah pengaruh gravitasi. Proses geomorfologi yang berlangsung adalah vulkanisme berupa transport material hasil erupsi dari kepundan gunungapi. Jenis material vulkanik yang tertransport antara lain lava dan piroklastik. Apabila terjadi hujan, endapan vulkanik pada bentuklahan ini juga dapat mengalami perombakan sehingga terangkut kembali sebagai aliran lahar dan diendapkan pada bentuklahan yang terletak pada bagian bawah yaitu kaki gunungapi, dataran kaki gunungapi, dan dataran fluviovulkan.

Lereng gunungapi memiliki ciri lereng lurus dengan unit relief bergelombang. Kemiringan lereng bagian bawah umumnya bervariasi $6 \%$ hingga $8 \%$ sedangkan bagian tengah hingga peralihan ke lereng atas mencapai $17 \%$. Sutikno dkk (2007) menjelaskan lereng gunungapi terletak di bagian bawah kerucut gunungapi dengan unit relief berbukit. Bentuklahan ini termasuk ke dalam fasies piroksimal dan fasies medial. Fasies piroksimal meliputi lereng bagian atas sedangkan fasies medial meliputi lereng bagian bawah. Lereng gunungapi terbentuk oleh pengendapan material piroklastik. Pengukuran dan pengamatan lapangan menunjukkan material penyusun lereng gunungapi adalah 
endapan piroklastik dan lahar. Endapan lahar dijumpai secara luas pada lereng bagian bawah dan menjadi bahan induk dalam perkembangan tanah (Gambar 3b). Proses yang berlangsung saat ini meliputi vulkanisme dari tenaga endogen dan pelapukan disertai erosi oleh tenaga eksogen. Vulkanisme ditandai oleh pengendapan material vulkanik pada saat terjadi erupsi. Sedangkan erosi terjadi oleh kerja aliran air yang berupa pembentukan alur-alur, parit, hingga pendalaman lembah dan erosi pada tebing sungai. Pengamatan pada lereng tengah menunjukkan terbentuknya alur-alur kecil dengan jumlah relatif sedikit. Bentuk erosi yang mendominasi adalah erosi lembar dengan wilayah yang terpengaruh pada daerah pengamatan mencapai $50 \%$.

Medan lava memiliki bentuk lereng lurus dengan kemiringan lereng 15\%. Unit relief bergelombang dan termasuk dalam kategori topografi agak curam. Bentuklahan ini termasuk dalam fasies piroksimal. Pengendapan material lava merupakan penciri utama fasies piroksimal. Disamping pengendapan lava, berdasarkan pengamatan yang dilakukan pada tiga titik sampel di ketinggian 1052 mdpal, 1083 mdpal, dan 1103 mdpal juga dijumpai endapan lahar. Pengendapan material lahar masih berlangsung pasca terjadinya erupsi tahun 2010. Material lahar cukup banyak dijumpai sebagai endapan permukaan. Berdasarkan pengamatan tipe batuan tersebut diketahui bahwa bentuklahan ini termasuk ke dalam kategori bentuklahan asal proses vulkanik, yang terbentuk karena proses pengendapan material gunungapi merapi muda yang juga dicirikan dengan banyaknya singkapan batuan. Proses geomorfologi pada saat ini berupa pengendapan material vulkanik khususnya pada saat terjadi erupsi. Proses eksogen berupa pelapukan disertai dengan erosi juga mulai banyak terjadi. Bentuk erosi yang banyak dijumpai adalah erosi parit dengan daerah yang terpengaruh bervariasi antara $<10 \%$ hingga $>50 \%$ daerah pengamatan. Indikator banyaknya daerah yang terpengaruh oleh erosi adalah keberadaan alur/parit hasil erosi dengan ukuran lebar dan kedalaman $10-50 \mathrm{~cm}$.

Kaki gunungapi memiliki ciri bentuk lereng lurus hingga cekung. Lereng cekung menandakan proses erosi terjadi pada bagian atas sedangkan proses deposisi berlangsung secara luas pada bagian bawah. Unit relief berombak hingga bergelombang dengan kemiringan lereng bervariasi 5-10\%. Pada beberapa lokasi pengukuran juga dijumpai kemiringan hingga $17 \%$. Bentuklahan ini termasuk dalam fasies medial. Kaki gunungapi terbentuk oleh pengendapan material vulkanik merapi muda dengan endapan permukaan berupa lahar yang masih banyak terdapat singkapan batuannya. Endapan lahar merupakan salah satu penciri fasies medial di wilayah ini (Gambar 3c). Perkembangan tanah umumnya telah menghasilkan tanah dengan solum tebal. Proses yang berlangsung saat ini adalah pengendapan material vulkanik, serta pelapukan disertai erosi. Pengendapan material vulkanik berlangsung pada lembah-lembah sungai utama baik pada saat erupsi maupun pasca erupsi. Disamping itu juga terdapat pengendapan material jatuhan pada saat erupsi pada wilayah yang lebih luas, tidak hanya terbatas pada lembah sungai utama. Material vulkanik sebagian besar telah mengalami pelapukan dan mulai dirombak oleh proses erosi. Keberadaan alur yang mengindikasikan berlangsungnya erosi bervariasi jumlah dan distribusinya. Bentuk erosi yang terjadi bervariasi yaitu berupa erosi lembar, alur, dan parit. Erosi lembar mempengaruhi area 25- 
$50 \%$, erosi alur berpengaruh lemah hingga sedang, adapun erosi parit berpengaruh sedang dengan area terpengaruh maksimal mencapai $50 \%$ dari luas sampel yang diamati.

Bentuklahan medan lahar berdasarkan jarak dari kepundan gunungapi terletak lebih jauh dibanding medan lava, atau berdasarkan elevasinya terletak pada kedudukan lebih rendah dari medan lava. Hal ini tidak terlepas dari proses pengendapan material lahar yang diangkut oleh aliran pada lembah sungai memungkinkan untuk mencapai jarak yang lebih jauh daripada pengendapan lava kental yang hanya terpengaruh oleh gravitasi. Medan lahar termasuk dalam fasies medial, dengan bentuk lereng lurus dan cekung, kemiringan lereng 9-17\%. Unit relief umumnya berombak, namun pada beberapa titik pengamatan juga dijumpai unit relief bergelombang. Material penyusun bentuklahan ini adalah endapan lahar (Gambar 3d). Endapan lahar merupakan bahan induk utama dalam perkembangan tanah. Proses geomorfologi yang berlangsung pada saat ini adalah pelapukan diikuti dengan erosi. Proses erosi yang berlangsung pada endapan lahar ini menunjukkan proses denudasi telah mulai berlangsung pada bentuklahan asal vulkanik. Bentuk erosi yang umum dijumpai adalah erosi lembar. Di beberapa tempat terdapat pula erosi alur. Daerah yang terpengaruh oleh erosi lembar $25-50 \%$, sedangkan erosi alur $25 \%$.

Dataran kaki gunungapi memiliki ciri bentuk lereng bervariasi yaitu cembung, cekung, dan lurus. Bentuk lereng lurus merupakan tipe yang paling banyak dijumpai. Unit relief termasuk dalam kategori topografi datar hingga berombak. Kemiringan lereng bervariasi dari $2 \%$ hingga $7 \%$. Bentuklahan ini termasuk fasies distal yaitu dicirikan dengan pengendapan material lahar. Sampel yang diambil pada satuan bentuklahan kaki gunungapi ini memiliki batuan induk berupa endapan gunung merapi muda dengan endapan permukaan berupa lahar, sehingga termasuk dalam fasiel distal. Berdasarkan data mengenai tipe batuan tersebut dapat dikenali bahwa bentuklahan ini termasuk kategori bentuklahan asal proses vulkanik yang terbentuk karena proses pengendapan material lahar. Proses geomorfologi yang berlangsung saat ini selain proses vulkanisme berupa pengendapan material vulkanik di sekitar lembah sungai utama, juga berlangsung proses pelapukan disertai erosi dalam wilayah yang luas. Tipe erosi umumnya berupa erosi lembar dan erosi alur. Erosi lembar mempengaruhi area 10-15\%. Pada salah satu lokasi pengamatan erosi lembar juga dapat mempengaruhi area seluas 30\% daerah pengamatan. Berlangsungnya pelapukan disertai erosi dan gerakan massa menandakan proses denudasi telah berlangsung sehingga dapat mengimbangi proses vulkanik.

Perbukitan terisolasi merupakan satu-satunya bentuklahan di daerah penelitian yang tidak tersusun oleh material gunungapi merapi muda. Secara genesis bentuklahan ini berbeda dengan bentuklahan lainnya karena terbentuk dari intrusi dan pengendapan material vulkanik merapi tua. Genesis ini dapat diidentifikasi berdasarkan material penyusun bentuklahan ini yaitu batuan intrusi yang berusia lebih tua dari wilayah sekitarnya. Bentuklahan perbukitan terisolasi memiliki bentuk lereng cembung dan cekung dengan kemiringan lereng mencapai 50\%. Unit relief berbukit dengan lereng terjal. Proses geomorfologi yang berlangsung saat ini pada perbukitan terisolasi adalah pelapukan, erosi, dan gerakan massa. Pelapukan telah menghasilkan tanah dengan 
tekstur lempungan. Gerakan massa yang terjadi berupa longsor dan rayapan. Bentuk erosi berupa erosi lembar dan erosi parit dengan daerah terpengaruh mencapai $20 \%$.

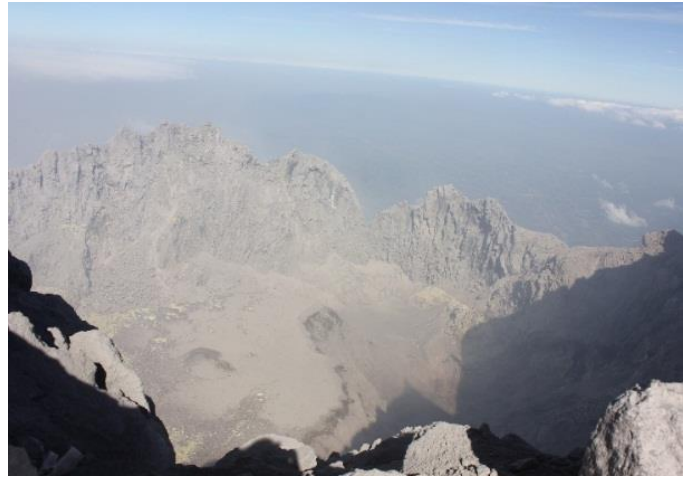

A

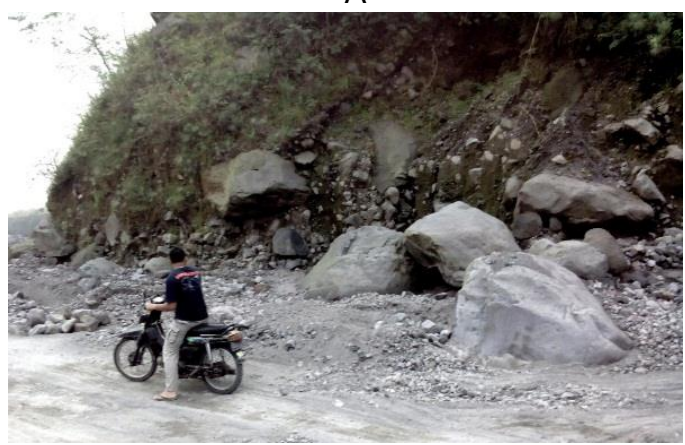

C

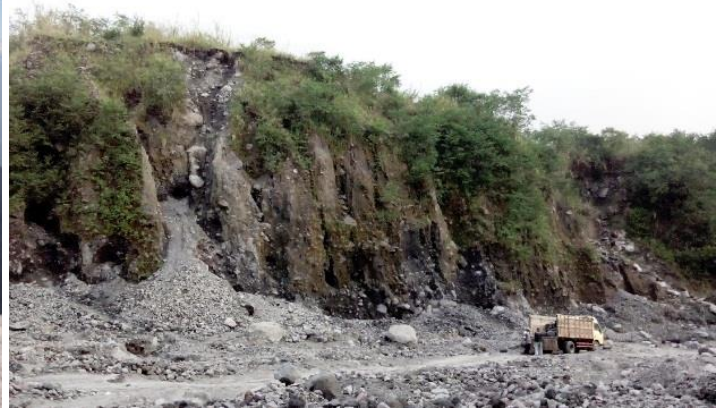

B

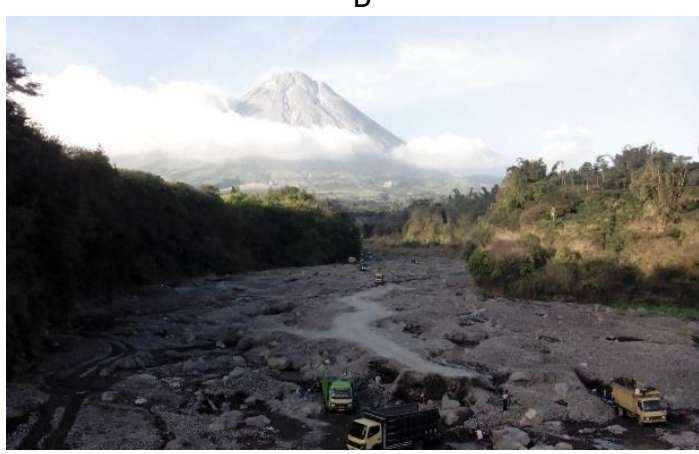

D

Gambar 3. Berbagai Kenampakan geomorfologis pada Lereng Baratdaya Gunungapi Merapi. (a) Bentuklahan Kepundan Gunungapi Merapi dilihat dari sisi utara (Sumber: data lapangan, 2014). (b) Endapan piroklastik pada satuan bentuklahan lereng bawah (Sumber: Data lapangan, 2015). (c) Material Endapan Lahar pada satuan bentuklahan Kaki Gunungapi (Sumber: Data lapangan, 2015). (d) Endapan material lahar pada lembah Sungai Bebeng, di wilayah peralihan antara satuan bentuklahan lereng bawah gunungapi dengan medan lahar.

\section{Tipe Bahaya Erupsi pada Lereng Baratdaya Gunungapi Merapi}

Bahaya erupsi yang terdapat pada masing-masing bentanglahan berbeda satu dengan lainnya. Bahaya erupsi dipengaruhi oleh kedudukan bentanglahan tersebut dari kepundan gunungapi sebagai sumber bahaya. Bentanglahan yang terletak lebih dekat dengan sumber bahaya memiliki potensi bahaya lebih besar. Disamping itu bahaya erupsi juga dapat diidentifikasi dari genesis bentuklahan dimana suatu bentuklahan terbentuk oleh proses tertentu selama periode erupsi. Informasi mengenai fasies gunungapi juga dapat digunakan dalam mengidentifikasi tipe bahaya erupsi pada suatu bentanglahan.

Secara umum bahaya erupsi yang terdapat pada Gunungapi Merapi sebagaimana dijelaskan oleh Sutikno dkk (2007) terdiri dari aliran lava, aliran piroklastik, serta aliran debu dan gas. Aliran lava diendapkan pada jarak 1 hingga $6 \mathrm{~km}$ dari puncak dan mendominasi pada ketinggian 1000 hingga 1200 meter, bahkan ada yang mencapai 
ketinggian 900 meter. Bentuklahan yang memiliki potensi bahaya aliran lava di daerah penelitian adalah kepundan gunungapi, kerucut gunungapi, lereng gunungapi, dan medan lava. Verstappen (2013) menjelaskan bahwa zona paling atas dalam tubuh gunungapi strato terbentuk oleh hancuran sumbat lava. Wilayah ini juga mencirikan fasies piroksimal yang tersusun oleh endapan lava. Keberadaan endapan lava merupakan bukti bahwa wilayah tersebut memiliki potensi bahaya aliran lava.

Aliran piroklastik bersumber dari puncak seperti aliran lava atau guguran kubah lava. Aliran piroklastik terjadi pada lereng tengah dan lereng bawah pada ketinggian 1000 meter hingga 700 meter yang berjarak 8-9 km dari puncak. Endapan aliran piroklastik cukup tebal dan memiliki pemilahan yang buruk. Bentuklahan yang memiliki potensi bahaya akibat aliran piroklastik adalah kepundan, kerucut gunungapi, medan lava, lereng gunungapi, dan medan lahar. Adapun aliran lahar terjadi pada bagian endapan piroklastik yang belum kompak sehingga terangkut sebagai aliran debris berkecepatan tinggi. Pada umumnya aliran lahar mengikuti lembah-lembah aliran sungai (Sutikno dkk, 2007)

Lebih lanjut Sutikno dkk (2007) menjelaskan bahwa pembahasan geomorfologi tidak akan terlepas dari jenis dan sebaran bahaya yang ditimbulkan oleh aktivitas vulkanik Gunungapi Merapi. Bahaya aliran lava antara lain dijumpai pada bentuklahan kepundan, kerucut gunungapi, lereng gunungapi, dan medan lava. wilayah ini memiliki ketinggian di atas $1000 \mathrm{mdpal}$ serta jarak terjauh dari kepundan $6 \mathrm{~km}$. Adapun bahaya aliran piroklastik dapat meluas hingga bentuklahan kaki gunungapi dan medan lahar dengan ketinggian di atas 700 mdpal. Permukiman penduduk terdapat pada bentuklahan kaki gunungapi dan medan lahar dengan ketinggian bervariasi antara 565 hingga 657 mdpal. Wilayah ini memiliki potensi bahaya aliran lahar.

Berdasarkan hasil pengharkatan diketahui di daerah penelitian terdapat tingkat bahaya erupsi sedang dan tinggi. tingkat bahaya erupsi sedang terdapat pada bentuklahan kaki gunungapi, medan lahar, serta lereng gunungapi bagian bawah. Tingkat bahaya erupsi tinggi terdapat pada bentuklahan kepundan, kerucut gunungapi, lereng gunungapi bagian atas, dan medan lava. Wilayah permukiman penduduk pada bentuklahan kaki gunungapi dan medan lahar memiliki tingkat bahaya erupsi sedang dengan jenis bahaya aliran lahar. Faktor utama yang mempengaruhi tingkat bahaya erupsi adalah jarak dari kepundan dan alur sungai, kemiringan lereng, serta unit relief. Jarak dari kepundan berkaitan dengan distribusi material hasil erupsi yang menimbulkan bahaya. Jarak akan semakin berpengaruh apabila kedudukan suatu tempat berada pada wilayah morfologi bukaan kawah (Sagala dan Yasaditama, 2012; Andreastuti dkk, 2006). Wilayah lereng baratdaya sejak masa lampau termasuk area berdekatan dengan bukaan kawah. Faktor kemiringan lereng dan konfigurasi relief berpengaruh dalam meningkatkan bahaya erupsi.

Pada erupsi tahun 2010 terdapat beberapa kerusakan pada wilayah lereng baratdaya dan barat Gunungapi Merapi. Kali Putih yang melintasi wilayah Kecamatan Srumbung mengalami kejadian banjir lahar terbanyak. Banyaknya material dan seringnya kejadian lahar menyebabkan kerusakan pada lingkungan di sekitar alur sungai, termasuk diantaranya bangunan pengendali sedimen (Hadmoko dkk, 2014). Di beberapa daerah 
juga terjadi kerusakan permukiman akibat banjir lahar yang dipengaruhi oleh jarak permukiman dari alur sungai dan tinggi endapan banjir lahar (Kumalawati dkk, 2014). Keberadaan berbagai jenis bahaya erupsi dan potensi wilayah untuk terlanda jenis-jenis bahaya tersebut merupakan faktor yang turut mempengaruhi persepsi masyarakat terhadap bahaya erupsi. Persepsi masyarakat selanjutnya berpengaruh terhadap keterlibatan dalam berbagai kegiatan pengelolaan bencana.

\section{Model Pengelolaan Lingkungan dan Kebencanaan pada Lereng Baratdaya Gunungapi Merapi}

Sutikno dkk (2007) menjelaskan bahwa Gunungapi Merapi sebagai bentanglahan vulkan muda memiliki potensi sumberdaya alam yang sangat tinggi. sumberdaya tersebut antara lain berupa sumberdaya lahan, sumberdaya air, sumberdaya mineral, dan sumberdaya hayati. Potensi sumberdaya lahan secara geomorfologis diidentifikasi dengan melakukan pengharkatan variabel kondisi pada bentuklahan yang mempengaruhi potensi lahan antara lain kemiringan lereng, ketebalan pelapukan, unit relief, keberadaan alur, dan laju erosi. Potensi sumberdaya lahan tinggi terdapat pada satuan bentuklahan dataran kaki gunungapi, serta sebagian wilayah kaki gunungapi dan medan lahar yang berbatasan dengan satuan bentuklahan dataran kaki gunungapi. Potensi sumberdaya lahan tinggi berdasarkan kondisi geomorfologis dipengaruhi oleh kemiringan lereng relatif landai, lapisan pelapukan tebal, tingkat erosi ringan dengan alur-alur bekas erosi sedikit dijumpai. Satuan bentuklahan dengan potensi sumberdaya lahan tinggi dapat dimanfaatkan sebagai lahan pertanian. Namun demikian untuk dapat melakukan pengelolaan yang baik, informasi kualitas lahan secara geomorfologis ini perlu didukung dengan informasi kondisi lahan lainnya seperti jenis batuan serta karakteristik iklim dan hidrologis.

Potensi sumberdaya lahan sedang terdapat pada bentuklahan lereng gunungapi, medan lava, serta sebagian medan lahar dan kaki gunungapi. Kemiringan lereng pada satuan bentuklahan ini miring hingga terjal dengan ketebalan pelapukan lebih tipis dan potensi erosi lebih besar baik erosi lembar maupun alur. Sumberdaya lahan dengan potensi sedang dapat dimanfaatkan untuk pertanian secara terbatas, tanaman tahunan, serta kawasan penyangga sebagai daerah resapan dengan jenis vegetasi besar. Adapun daerah dengan potensi sumberdaya rendah terdapat pada kerucut gunungapi dan kepundan gunungapi yang berdekatan dengan sumber bahaya erupsi, kemiringan lereng sangat terjal, relief bergunung, serta potensi erosi besar.

Wilayah lereng baratdaya Gunungapi Merapi yang termasuk dalam bagian Merapi Muda memiliki potensi sumberdaya air tinggi. Sutikno dkk (2007) menjelaskan potensi sumberdaya air Gunungapi Merapi dicerminkan oleh sifat dan debit aliran sungai. Disamping itu potensi sumberdaya air juga ditunjukkan oleh kondisi akuifer. Satuan kaki gunungapi pada lereng baratdaya Gunungapi Merapi memiliki produktivitas akuifer sedang, sedangkan dataran kaki gunungapi memiliki produktivitas akuifer tinggi. Dalam kaitannya dengan kondisi geomorfologis, lereng baratdaya Gunungapi Merapi dapat dibedakan ke dalam recharge area dan discharge area. Dengan memperhatikan indikator 
bentuklahan, kemiringan lereng, jenis material permukaan, ketinggian tempat, dan ketebalan pelapukan, dapat diperkirakan wilayah produksi airtanah meliputi bentuklahan kerucut gunungapi dan lereng gunungapi sedangkan wilayah pemanfaatan airtanah pada bentuklahan kaki gunungapi, dataran kaki gunungapi, medan lava, dan medan lahar. Berdasarkan pengharkatan variabel tersebut, satuan bentuklahan lereng bawah gunungapi juga memiliki potensi sebagai daerah pemanfaatan airtanah. Pada wilayah peralihan antara bentuklahan lereng gunungapi, kaki gunungapi, dan dataran kaki gunungapi terdapat tekuk lereng (break of slope) yang memunculkan banyak mataair sebagai sabuk mataair (Simoen, 2001; Sutikno dkk, 2007).

Potensi sumberdaya hayati dapat diidentifikasi berdasarkan keanekaragaman flora dan fauna. Gunungapi Merapi sebagai vulkan aktif memiliki distribusi vegetasi yang unik, baik dalam kaitannya dengan distribusi berdasarkan ketinggian tempat maupun distribusi jenis vegetasi tertentu yang beradaptasi dengan proses vulkanisme. Van Steenis (2010) menjelaskan, Gunungapi Merapi sebagaimana gunungapi dan pegunungan lain di Pulau Jawa memiliki pembagian wilayah berdasarkan ketinggian yang berkorelasi dengan zonasi vegetasi, atau biasa disebut sebagai demarkasi floristik. berdasarkan pembagian tersebut, daerah penelitian terdiri dari tiga zona yaitu (1) zona tropik (100 hingga 1000 mdpal), (2) zona pegunungan (1000 hingga $2400 \mathrm{mdpal}$ ), (3) zona sub alpin (2400 mdpal hingga pucak Gunungapi Merapi pada ketinggian sekitar 2900 mdpal). Zona tropik dijumpai pada bentuklahan dataran kaki gunungapi, kaki gunungapi, serta medan lahar. Bentuklahan yang berada pada zona tropik ini memiliki potensi untuk dikelola sebagai zona pertanian lahan basah, pertanian lahan kering dan permukiman. Pada sub zona bukit, secara alami wilayah ini memiliki jenis vegetasi hutan tinggi. Zona pegunungan dijumpai pada bentuklahan lereng gunungapi dan medan lava.

Selain zonasi vegetasi dari demarkasi floristik, Gunungapi Merapi sebagai vulkan aktif juga memiliki keunikan jenis vegetasi. Keunikan vegetasi ini dari sudut pandang sumberdaya hayati juga merupakan potensi yang bernilai baik secara ekosistem maupun ilmu pengetahuan. Van Steenis (2010) menjelaskan bahwa terdapat jenis tumbuhan tertentu yang dapat bertahan hidup pada lingkungan vulkan aktif. Terdapat jenis tumbuhan pionir yang sangat kerdil dan tumbuh merunduk, khususnya pada lokasi-lokasi yang terlindung dari angin dan gas beracun. Jenis-jenis tumbuhan yang dijumpai di sekitar wilayah kepundan adalah Vaccinium varingiaefolium, Rhododendrom retusum, dan paku Selliguea feei, kadang-kadang disertai beberapa lumut. Jika kawah punah, vegetasi pionir segera menyelinap masuk yang kemudian berkembang menjadi hutan elfin Cantigi (Vaccinium). Di wilayah Gunungap Merapi yang sangat aktif, Cantigi dijumpai pada kerucut gunungapi namun tidak berkembang di sekitar kepundan gunungapi. Bahkan pasca erupsi tahun 2010 berdasarkan observasi pada bibir kawah pada tahun 2013 dan 2014 belum terdapat vegetasi yang tumbuh kembali.

Aktivitas vulkanik Gunungapi Merapi menghasilkan material endapan lava, piroklastik dan lahar, serta timbunan abu. Pasca erupsi pada wilayah-wilayah yang terdapat material ini juga dapat berkembang vegetasi pionir. Pada endapan aliran lava umumnya vegetasi dapat berkembang apabila telah terjadi proses pelapukan. Jenis 
vegetasi pionir aliran lava menurut Van Steenis (2010) adalah Schefflera rigida, Arundinella setosa, Myrica javanica, dan Ficus deltoidea. Pada lereng baratdaya Gunungapi Merapi tumbuhan pionir mulai berkembang sebagai semak-semak rendah menyerupai stepa. Vegetasi pionir pada endapan lava dapat dijumpai pada bentuklahan medan lava dan lereng gunungapi.

Pada material timbunan abu jenis vegetasi yang berkembang adalah Carex bacans dan Annaphalis (Gambar 4). Bekas timbunan abu sebagian telah mengalami pelapukan. Timbunan abu dijumpai pada bentuklahan kepundan, kerucut gunungapi, lereng gunungapi, dan kaki gunungapi. Aliran lahar terdistribusi lebih luas pada berbagai satuan bentuklahan yaitu pada lembah-lembah sungai, terutama pada bentuklahan lereng gunungapi dan kaki gunungapi. Jenis vegetasi pionir pada endapan lahar adalah Trema orientalis dan Parasponia parviflora.

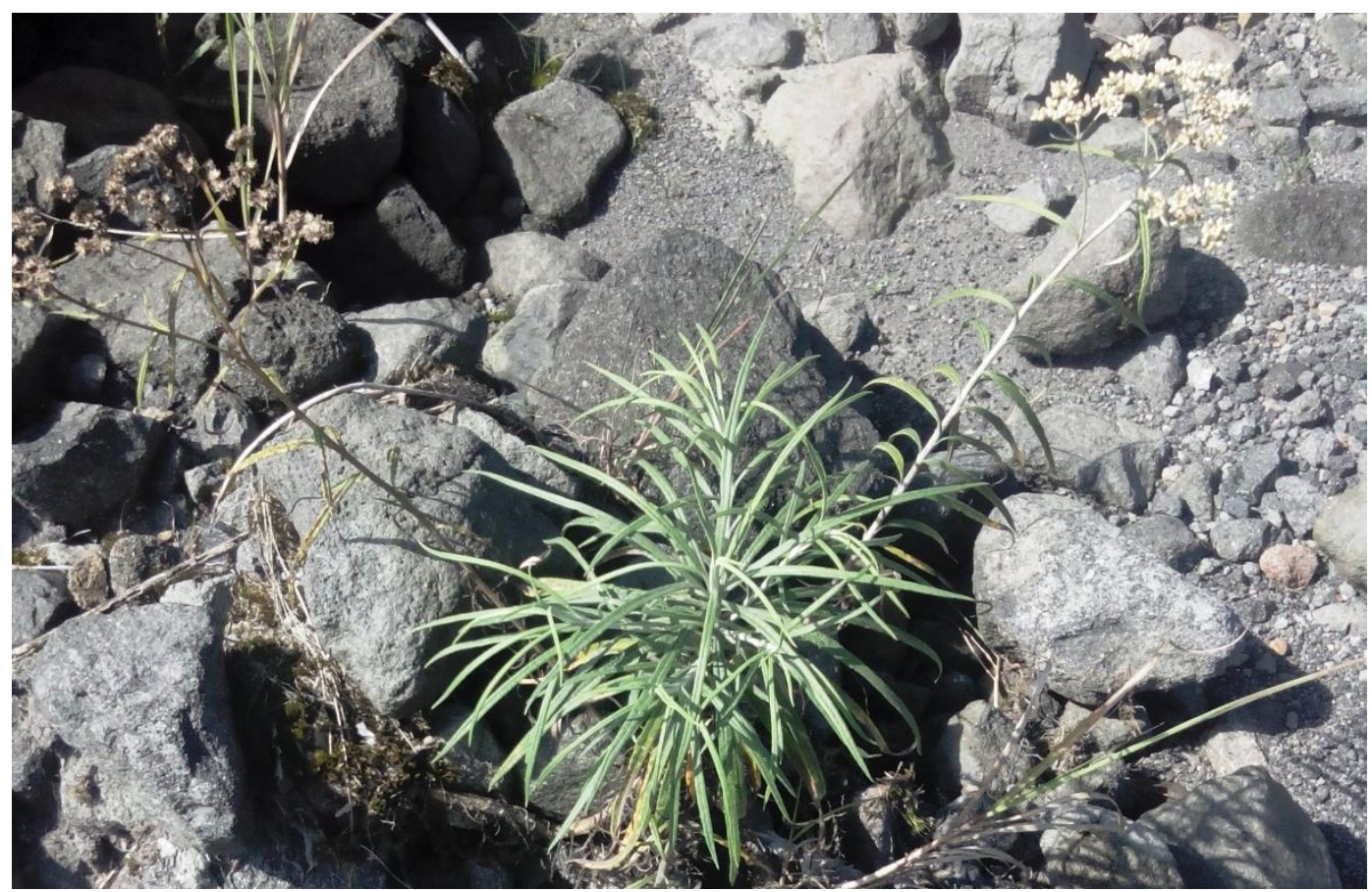

Gambar 4. Annaphalis, salah satu jenis tumbuhan pionir yang dijumpai pada satuan bentuklahan medan lava, dengan tinggi batang rata-rata $30 \mathrm{~cm}$.

Dalam upaya pengelolaan kebencanaan, penataan ruang untuk mitigasi bencana juga dapat dilakukan dengan pendekatan geomorfologi. Wilayah yang tercakup mulai dari satuan bentuklahan lereng gunungapi yang mempengaruhi distribusi material erupsi. Penataan ruang pada satuan bentuklahan lereng gunungapi dapat dilakukan dengan pelestarian kawasan hutan yaitu dengan vegetasi alami. Hutan ini memiliki fungsi sebagai penahan laju material erupsi dari kerucut gunungapi. Material erupsi yang memasuki alur lembah sebagian dapat tertahan oleh vegetasi sehingga mengurangi kecepatan laju saat memasuki alur lembah. Jenis vegetasi yang dapat dikembangkan adalah vegetasi asli baik yang masih dijumpai maupun yang rusak karena erupsi sehingga perlu dikembangkan 
kembali dengan cara introdusir. Jenis yang dapat dikembangkan antara lain rasamala (Altinga excelsa), puspa (Shima walichii), sarangan (Castanopsis argantea), urang-urang (Debregasia longifolia), kemlandingan gunung (Albizia lophantha), cantigi (Vaccinium), sengon gunung (Albizia falcataria), sawa (Engelhardia spicata), dan pasang (Lithocarpus sundaicus). vegetasi tersebut memiliki karakteristik kapasitas intersepsi hujan tinggi, tidak mengurangi airtanah dalam jumlah besar, dapat segera mengalami regenerasi apabila mengalami kebakaran akibat aliran lava dan piroklastik, serta merupakan tumbuhan pionir pada bentanglahan vulkanik.

Wilayah kaki gunungapi di bawah lereng gunungapi banyak terdapat pemukiman dan pengusahaan penduduk seperti pertanian, peternakan, dan pertambangan. Bahaya yang mengancam dapat berupa awan panas, lahar hujan, dan juga material jatuhan. Begitu juga dengan wilayah dataran kaki dan dataran fluvial merupakan wilayah padat penduduk yang dapat terdampak lahar hujan. Penataan ruang dapat dilakukan dengan mitigasi struktural. Mitigasi struktural dilakukan dengan penataan wilayah pemukiman, dan pertanian dengan buffrering sedangkan pada alur sungai dengan pembuatan dam dan tanggul. Pada hulu sungai dapat dilakukan pembuatan dan perbaikan dam penahan sedimen yang berfungsi untuk mengurangi volume sedimen masuk alur sungai. Selain itu juga dapat dibuat dam pengarah yang berfungsi untuk mengalirkan aliran sedimen pada sungai utama. Dam pengarah dilengkapi dengan tanggul yang berfungsi mengurangi kecepatan aliran sedimen.

Pada daerah tengah yang merupakan daerah yang padat penduduk dan juga terdapat aktivitas pertanian pada alur sungainya dapat dibuat dam. Konsolidasi dam ini memiliki talud yang terdapat di kanan dan kiri sungai. Talud digunakan untuk melindungi tebing sungai dari gempuran aliran sedimen sehingga tidak menimbulkan longsor pada tebing. Namun walaupun sudah dibangun talud sedimen hasil erupsi dapat keluar alur sungai karena alur sungai penuh dengan sedimen atau pada penggal kelokan sungai. Selain itu luapan sedimen juga dapat terjadi pada penggal sungai pada tekuk lereng (break of slope) pada wilayah ini sedimen akan mengalir lebih cepat karena terdapat perbedaan ketinggian. Untuk mengurangi kerusakan yang ditimbulkan dapat dilakukan dengan buffering pada sempadan sungai dibiarkan menjadi area alami selain adanya talud pada wilayah ini juga dihijaukan dengan vegetasi penahan yang berfungsi menahan luapan sedimen contoh vegetasi alami berupa bambu. Bambu memiliki karakteristik yang rapat sehingga mampu menahan luapan dan menahan longsor tebing. Setelah vegetasi alami baru kemudian lahan pertanian dan perternakan kemudian pemukiman.

\section{SIMPULAN}

Lereng baratdaya Gunungapi Merapi memiliki kondisi geomorfologi yang bervariasi. Terdapat berbagai bentuklahan yang memiliki perbedaan relief, batuan, stuktur, dan proses geomorfologi yang berbeda yang berimplikasi pada perbedaan potensi sumberdaya dan jenis bahaya apabila terjadi erupsi. Bentuklahan pada lereng baratdaya Gunungapi Merapi memiliki genesis asal vulkanik. Proses geomorfologi yang berlangsung saat ini umumnya adalah vulkanisme, yaitu pengendapan material vulkanik 
berupa lava, piroklastik, lahar, dan tuff. Proses eksogen mulai berpengaruh secara kuat pada beberapa bentuklahan ditandai oleh ketebalan pelapisan pelapukan dan proses erosi. Kondisi geomorfologi pada lereng baratdaya Gunungapi Merapi berpengaruh terhadap potensi bahaya dan sumberdaya. Jenis bahaya erupsi yang dijumpai antara lain aliran lava, aliran piroklastik, dan aliran lahar. Potensi sumberdaya yang dapat diidentifikasi berdasarkan kondisi geomorfologis adalah sumberdaya lahan, sumberdaya air, dan sumberdaya hayati.

\section{UCAPAN TERIMA KASIH}

Tulisan ini disusun dari hasil penelitian dengan judul Survei Geomorfologikal Analitikal untuk Penyediaan Informasi Geomorfologi dalam Mendukung Pengelolaan dan Lingkungan di Lereng Baratdaya Gunungapi Merapi, yang dibiayai dengan dana DIPA FIS UNY Tahun 2015. Penulis mengucapkan terima kasih kepada Fakultas IImu Sosial UNY yang telah membiayai penelitian ini. Ucapan terima kasih juga kami haturkan berbagai pihak yang telah membantu hingga terselesaikannya penelitian ini.

\section{DAFTAR PUSTAKA}

Andreastuti, S,D., Newhall, C., dan Dwiyanto, J. 2006. Menelusuri Kebenaran Letusan Gunung Merapi 1006. Jurnal Geologi Indonesia 1 (4): 201-207.

Hadi, B.S. dan Setyawati, S. 2014. Penyusunan Sistem Informasi Bahaya dan Risiko Bencana Erupsi Gunungapi Merapi Pasca Erupsi 2010. Laporan Penelitian Hibah Bersaing Tahun Ke-1. LPPM UNY

Putra, T.Y.D., Aditya, T., de Vries, W. 2011. A Local Spatial Data Infrastructure to Support the Merapi Volcanic Risk Management: A Case Study at Sleman Regency, Indonesia. The Indonesian Journal of Geography 43 (1): 25-48.Sagala, S.A.H. dan Yasaditama, H.I. 2012. Analisis Bahaya dan Resiko Bencana Gunungapi Papandayan, Studi Kasus Kecamatan Cisurupan Kabupaten Garut. Forum Geografi 26 (1): 1-16.

Simoen, S. 2001. Sistem Akuifer di Lereng Gunungapi Merapi Bagian Timur dan Tenggara, Studi Kasus di Kompleks Mataair Sungsang Boyolali Jawa Tengah. Majalah Geografi Indonesia 15 (1): 1-16.

Sudibyakto. 2007. Potensi Bencana Alam Dan Kesiapan Masyarakat Menghadapi Bencana (preparedness for Vulnerable Communities). Pengantar Diskusi Bulanan. Pusat Studi Pedesaan dan Kawasan (PSPK) Universitas Gadjah Mada. 4 Oktober 2007.

Sudibyakto. 2011a. Risiko Bila Merapi Meletus. dalam Manajemen Bencana Indonesia Kemana?. Yogyakarta: Gadjah Mada University Press.

Sudibyakto. 2011 ${ }^{\mathrm{b}}$. Mengelola Risiko Bencana. dalam Manajemen Bencana Indonesia Kemana?. Yogyakarta: Gadjah Mada University Press.

Sudradjat, A., Syafei, I., dan Paripurno, E.T. 2010. The Characteristics of Lahar in Merapi Volcano, Central Java as the Indicator of the Explosive during Holocene. Jurnal Geologi Indonesia 6 (2): 69-74

Sutikno., Widiyanto., Santosa, L.W. dan Purwanto, T.H. 2007. Kerajaan Merapi, Sumberdaya Alam dan Daya Dukungnya. Yogyakarta: BPFG

Thornbury, W.D. 1969. Principles of Geomorphology. New York: John Wiley and Sons. 
Undang-Undang Republik Indonesia Nomor 24 Tahun 2007 tentang Penanggulangan Bencana, LNRI Tahun 2007 Nomor 66, TLNRI Nomor 4723.

Verstappen, H. Th. 2014. Geomorfologi Terapan, terjemahan oleh Sutikno. Yogyakarta: Penerbit Ombak.

Verstappen, H. Th. 2013. Garis Besar Geomorfologi Indonesia, Terjemahan oleh Sutikno. Yogyakarta: Gadjah Mada University Press

Verstappen, H. Th. 1983. Applied Geomorphology. Amsterdam: Elsevier. 